\title{
Adoption of Recommended Rice Production Practices among Women Rice Farmers in Nasarawa State, Nigeria \\ Http://dx.doi.org/10.4314/jae.v20i1.9
}

\section{Kagbu, J. H.}

Department of Agricultural Extension and Economics,

National Agricultural Extension \& Research Liaison Services, Ahmadu Bello University, Zaria.

Email: jkagbu@gmail.com, Phone: +2348133344843

Omokore, D. F.

Department of Agricultural Extension \& Rural Sociology, Ahmadu Bello University, Zaria.

Email: daveomokore@yahoo.com Phone: +238037862916

Akpoko, J. G.

Department of Agricultural Extension \& Rural Sociology, Ahmadu Bello University, Zaria. Email: josephgamboakpoko@gmail.com, +238033973686

\section{Abstract}

This study assessed the factors influencing adoption of recommended rice production practices by women farmers in Nasarawa State. A total of 203 women rice farmers were selected for the study using multistage sampling procedure. Data were collected using structured interview schedule. Descriptive statistics and multiple regressions were used for data analysis. Results reveal that the majority (70.9\%) of the respondents was less than 45 years old, married (82.5\%), had below secondary education (80.0\%), had farming experience of 10 years and above (80\%), and inherited their farmlands (81.4\%). Farm size (2.6353, $P<0.05)$ was the only socio-economic factor which significantly influenced adoption of recommended rice production practices by women rice farmers in the study area. Constraints hindering adoption of RRPPs were unavailability of credit facilities, poor marketing system and unstable price, and inadequate extension contacts. It was recommended that government should ensure that credit facilities are made available and accessible to women farmers. Also, buy-back arrangement should be introduced in order to ensure good pricing for rice producers.

Key words: Rice production of women, factors influencing adoption of rice production practices by women

\section{Introduction}

Agriculture constitutes the main source of livelihood of people in many parts of the world. In Nigeria, agriculture is one of the most important sectors of the Nigerian economy which provides employment opportunity for about 70-80 percent of the total population most of whom are practicing farming at subsistence level (Akande, 2000). 
Creative commons User License: CC BY-NC-ND

Abstracted by: EBSCOhost, Electronic Journals Service (EJS),

Google Scholar, Directory of Open Access Journals (DOAJ),

Journal Seek, Scientific Commons,

Food and Agricultural Organization (FAO), andCABI
Journal of Agricultural Extension

Vol. 20 (1) June, 2016

ISSN(e): 24086851; ISSN(Print); 1119944X

http://journal.aesonnigeria.org

http://www.ajol.info/index.php/iae

Email: editorinchief@aesonnigeria.org

The National Policies on agricultural food production in Nigeria has explicitly made several efforts in an attempt to address the need to increase food production in order to meet the food security objectives by giving priority to self-sufficiency in staple food production especially rice among other food crops in Nigeria (Ayoola, 2007).

West African Rice Development Association (WARDA) (2006) projected growth in rice consumption for Nigeria as high as 4.5 percent per annum. In response to the growing demand for this staple food crop, governments at various periods actively interfered in the economy coming up with policies and programme to this effect. An estimate of locally produced rice for the year 2002 was 2.9 million tons (WARDA, 2003; Imolehin and Wada, 2010). Also, only about 67 percent of the 25 million hectares of land cultivated to various food crops were cultivated to rice between 2000 and 2002 (Obinna, 1991). Throughout the period, rice output increased, but decreased in 1991-1995 periods. Rice yield could increase due to growers using improved rice varieties which have potential to improve nutrition, boost food security, foster rural development and support sustainable land care (Ajani, 2008).

Unfortunately, the domestic production of rice has not met the demand, leading to food shortage problems. FAO (2002) projected annual growth in rice consumption for Nigeria as $4.5 \%$ beyond 2000 . In a bid to address the demand/supply gap for rice, the government at various times had come up with policies and programmes such as rice importation to supplement the local production which no doubt continues to drain the country's hard earned foreign exchange earnings. FAO (2008) estimated that Nigerian rice import increases from 2630 tonnes in 1980 to 1876 million tonnes in 2002. The total import also stood at 1.9 million tonnes in 2003 (Central Bank of Nigeria (CBN), 2004). However, continued fluctuation in rice production in the country is an indication of limited capacity of the Nigeria rice economy to match the domestic demand which can be attributed to the inability of the rice farmers to obtain maximum output from the resources committed to the enterprise (Kolawole, Oladele, Alarima, and Wakatsuki, 2012). For instance, an average yield of rice in Nigeria is 1.8 tonnes / hectare compared to 3.0 tonnes / hectare from a country like Cote d'Ivoire and Senegal (WARDA and NISER, 2001). The existing level of production in rice in the country reflects low level of production efficiency of rice farmers in the country. This could be a result of non-adoption of appropriate production practices.

Rural women farmers play a vital role in food production and food security. They account for $70 \%$ of agricultural workers, $80 \%$ of food producers, $100 \%$ of those who process basic foodstuffs and they undertake from $60 \%$ to $90 \%$ of the marketing (Fresco, 1998). Four of ten agricultural workers in the world are women (United Nations, 1986). Women take part actively in farming activities and in processing farm products, in addition to their domestic and reproductive responsibilities. It is often stated that women are responsible for more than half the world's food production overall and produce up to 60 to $80 \%$ of basic foodstuff in Africa (Fresco, 1998). The role women play in agriculture and the rural society is fundamental to agricultural and rural development in sub-Saharan Africa.

In Nigeria, women supply most of the needed labour in agricultural activities and this is the most important factor of production to farmers, as it is needed at the stages of agricultural production. Yahaya (2002) recorded that $76 \%$ of women from Oyo and 
Creative commons User License: CC BY-NC-ND

Abstracted by: EBSCOhost, Electronic Journals Service (EJS),

Google Scholar, Directory of Open Access Journals (DOAJ),

Journal Seek, Scientific Commons,

Food and Agricultural Organization (FAO), andCABI
Journal of Agricultural Extension

Vol. 20 (1) June, 2016

ISSN(e): 24086851; ISSN(Print); 1119944X

http://journal.aesonnigeria.org

http://www.ajol.info/index.php/iae

Email: editorinchief@aesonnigeria.org

Bauchi State are actively involved in farming activities or are engaged in their husband's farms.

It has been reported by different authors that inadequate information about the improved technologies was one of the constraints in agricultural production. Women do not have adequate access to agricultural information and innovations (Saito and Surling, 1993). Folasade (1991) emphasized that lack of separate land for women and inadequate contact with extension agents are serious constraints faced by women farmers. Women very rarely own land in Nigeria, despite their heavy involvement in agriculture. Because women generally do not own land or other assets it has traditionally been difficult for women to obtain bank loans or other forms of credit through the banking system. Land tenure system is largely by inheritance. This lack of title to land, according to Famoriyo (1979), prevents women from exercising or improving their expertise in crop production and animal husbandry because of security of tenure. The majority of them use low yielding and unimproved planting materials, primitive and labour intensive farm implements, traditional farming practices, which have adversely affected agricultural production.

Food and Agriculture Organization (FAO) (2006), have identified some barriers which are associated with low adoption of improve rice production technologies by women farmers. This includes: large investment cost, perceive risk associated with new technology, long gestation period for the benefit of the technology to materialize, poor access to information and extension services, land tenure, culture and recent history. The socio-economic status of women farmers such as marital status, family income, education level, occupation and social status also affect technology adoption.

The gap between rice demand and domestic supply has further been widened over decades among households across the country. This has culminated in a situation whereby domestic supply has been complemented with enormous rice import in consequence of which Nigeria has emerged a major importer of rice in the West African sub-region (Saka, Okoruwa and Ajibola, 2005). Currently, Nigeria is the world's second largest importer, importing 2 milliontons of rice worth 365 billion annually (FMARD, 2011).

In response to the prevailing rice supply deficit situation in the country, successive Nigerian government have intervened in the rice sub-sector by increasing tariff on rice importation so that local production could be encouraged in order to widen the home market for the nation local rice (Badawi, 2004). However, Nasarawa State Agricultural Development Programme (NSADP, 2010) reported that rice production packages are often rejected by women rice farmers in the State due to high cost of adoption, lack of accessibility and complexity of some of the rice production packages disseminated to the farmers. These factors also serve as an impediment to the adoption of recommended rice production packages by women rice farmers in western zone of Nasarawa State. Furthermore, FMARD (2012) identified inappropriate technology, inadequate new varieties, limited awareness on the use of improved seed, coupled with poor distribution channels, poor seed quality, and adulteration of seed as major constraints in the rice subsector. Despite the significant role of women in rice production in Nasarawa State, studies carried out to examine the factors influencing adoption of recommended rice production practices are 
inadequate. Also, data on how recommended rice production practices are being adopted by farmers in Nigeria is very scanty.

The broad objective of the study is to assess the socio-economic factors influencing adoption of recommended rice production practices by women farmers in western zone of Nasarawa State. The specific objectives of the study are to describe the socio-economic characteristics of women rice farmers; determine the factors influencing the adoption of recommended rice production practices among women rice farmers, and identify the constraints faced by women farmers in rice production in the study area. This study hypothesized that here is no significant relationship between women rice farmers' socio-economic characteristics and the adoption of RRPPs.

\section{Methodology}

The study was carried out in western zone of Nasarawa State. Nasarawa State is bounded in the north by Kaduna State, in the west by the Federal Capital Territory (Abuja), in the south by Kogi and Benue States and in the east by Taraba and Plateau States. The State is located in Southern Guinea Savanna belt of the country and occupies a total land area of 28,682 square kilometres with a population of $1,869,377$ (NPC, 2006). The western zone comprises of five local government areas: Karu, Keffi, Kokona, Nasarawa, and Toto. The selected Local Government Area used for the study area is depicted in Figure 1.

Nasarawa State has agriculture as the mainstay of its economy with the production of varieties of cash crops throughout the year. The State is predominantly agrarian with the majority of the population actively involved in farming. Other food crops produced within the study area apart from rice include yam, beniseed, sorghum, melon, cassava, cowpea and maize (NASADP, 2008). Rice occupies a dominant position among arable crops grown in the Western Agricultural Zone of Nasarawa State. Farmers in the zone cultivate rice as sole crop in the field and or as intercrop with others such as maize and cocoyam. Nasarawa State is one of the major rice producing areas in Nigeria where production capacity was estimated at 655,000 metric tons/ha from 2003-2008 (Nasarawa State Agricultural Development Project (NADP), 2010). Between 2007 and 2014, an estimated land area of 642.16 ha produced an estimated 1,449,000 metric tonnes of rice (NAERLS Agricultural Performance Survey of Wet Season 2007 -2014). 


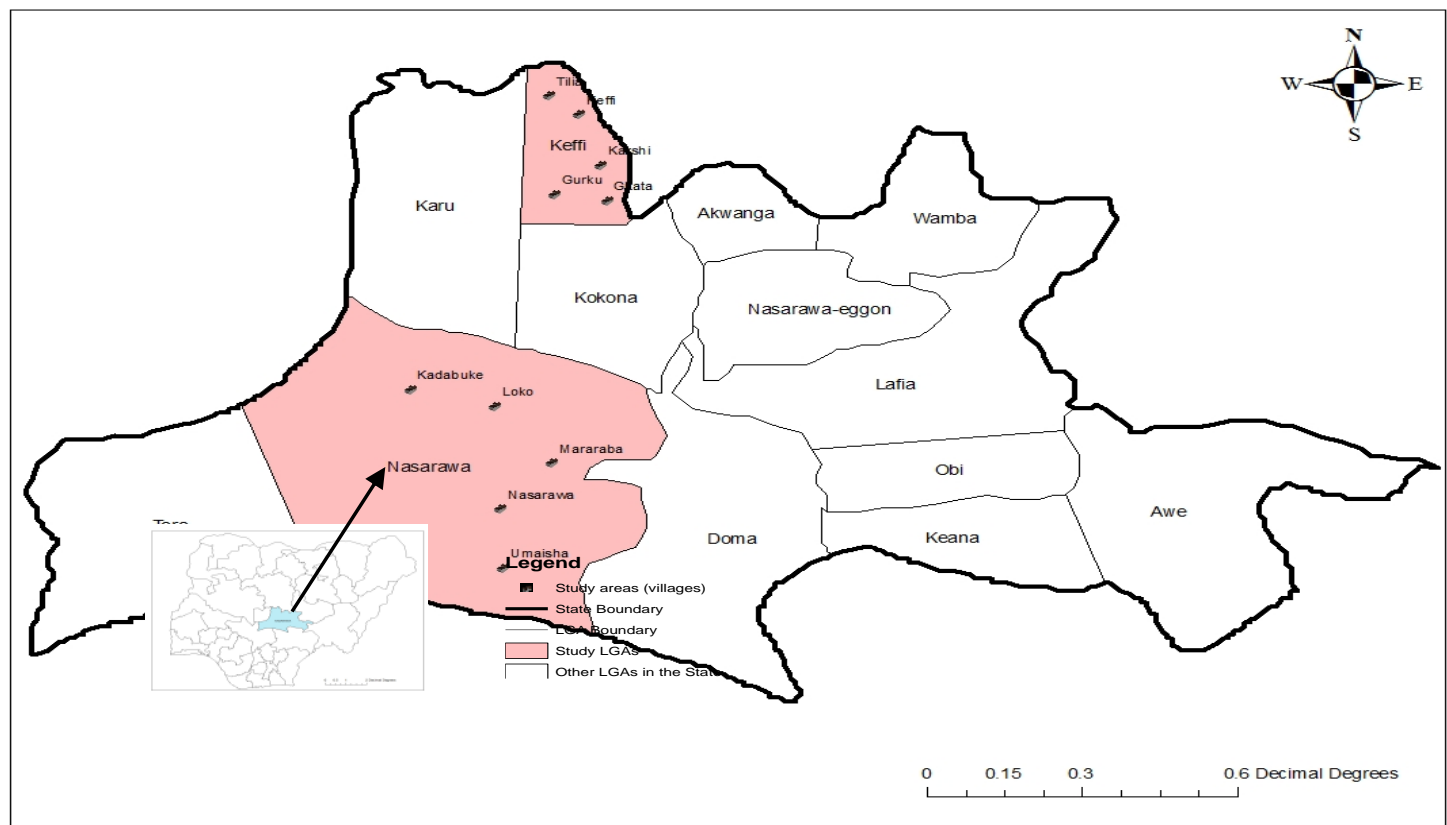

Figure 1: Map of Nasarawa State showing the study area

Women who are involved in rice production in western zone of Nasarawa State constitute the population of study. Multi-stage sampling technique was used to select the women rice farmers for this study. The first stage was the purposive selection of two LGAs from the zone. The second stage was a purposive selection of five major rice-producing villages in each Local Government Area. The selection in the first and second stage was based on the prominence of rice production as well as the predominance of women's involvement. The third stage was random selection of women rice farmers in the selected villages. Ten percent of the women rice farmers were selected per village. In all, a total of 203 women rice farmers were used for this study.

Primary data were used for this study. The primary data were collected through the use of structured interview schedule which was administered to two hundred and three (203) women rice farmers from the ten selected villages. Enumerators were used to administer the interview schedule on the farmers. Women rice farmers were visited to collect relevant data. Descriptive statistics were employed to describe the socio-economic characteristics of women rice farmers, and the constraints facing women rice farmers in the study area. Multiple regression model was used to determine the socio-economic factors influencing the level of adoption of recommended rice production practices by women farmers. Multiple regression was also used to test the stated hypothesis. The multiple regression model is expressed as:

Where:

$$
Y=a+b_{1} X_{1}+b_{2} X_{2}+b_{3} X_{3}+b_{4} X_{4}+b_{5} X_{5}+\cdots b_{10} X_{10}+U
$$

$\mathrm{Y}=$ Adoption of recommended rice production practices (measured in numbers) $\mathrm{a}=$ Constant 
$\mathrm{X}_{1}=$ Age of women rice farmers (in years)

$\mathrm{X}_{2}=$ Marital status (Married $=3$, Single $=2$ or widow $=1$ )

$X_{3}=$ Years of formal Education (in years)

$\mathrm{X}_{4}=$ Household size (number)

$\mathrm{X}_{5}=$ Farming experience (in years)

$\mathrm{X}_{6}=$ Farm size (ha)

$\mathrm{X}_{7}=$ Land acquisition (inheritance, lease, gift, purchase)

$X_{8}=$ Membership of cooperative societies (Number)

$X_{9}=$ Income/Amount of credit received ( $\#$ )

$\mathrm{X}_{10}=$ Access to Information (Number of sources)

$\mathrm{U}=$ Error term

\section{Results and Discussion}

\section{Socio-economic characteristics of women rice farmers}

Result in Table 1 indicates that the majority (70.9\%) of the women rice farmers were less than 45 years old. This means that women rice farmers in the study area were of average age. The implication could be that the acceptance of farm decisions with regards to adoption of improved technologies could be positively influenced. This is in line with the findings of Mustapha, Undiandeye, Sanusi and Bakari (2012) who found that the majority of rice farmers were within age range of 41-50 years old. 
Creative commons User License: CC BY-NC-ND

Abstracted by: EBSCOhost, Electronic Journals Service (EJS), Google Scholar, Directory of Open Access Journals (DOAJ), Journal Seek, Scientific Commons,

Food and Agricultural Organization (FAO), andCABI
Journal of Agricultural Extension

Vol. 20 (1) June, 2016

ISSN(e): 24086851; ISSN(Print); 1119944X

http://journal.aesonnigeria.org

http://www.ajol.info/index.php/jae

Email: editorinchief@aesonnigeria.org

Table 1: Distribution of women rice farmers according to socio-economic characteristics

\begin{tabular}{|c|c|c|c|c|}
\hline Variables & Percentage & Variables & Percentage & Mean \\
\hline Age (Years) & & & & 41 \\
\hline $15-24$ & 5.9 & $25-34$ & 30.5 & \\
\hline $35-44$ & 34.5 & $45-54$ & 19.2 & \\
\hline 55 and above & 9.9 & & & \\
\hline \multicolumn{5}{|l|}{ Marital Status } \\
\hline Married & 82.8 & Single & 2.9 & \\
\hline Divorced & 2.5 & Widowed & 11.8 & \\
\hline \multicolumn{5}{|l|}{ Education } \\
\hline No Formal Education & 10.3 & Adult Education & 33.3 & \\
\hline Primary Education & 38.7 & $\begin{array}{l}\text { Secondary } \\
\text { Education }\end{array}$ & 14.7 & \\
\hline Tertiary Education & 2.5 & & & \\
\hline Household Size & & & & 8 \\
\hline $1-5$ & 32.4 & $6-9$ & 40.2 & \\
\hline $10-15$ & 16.2 & 16 and Above & 10.7 & \\
\hline Years of Farming Experience & & & & 18 \\
\hline $0-9$ & 20.6 & $10-29$ & 24.5 & \\
\hline $20-29$ & 25.5 & $30-39$ & 15.2 & \\
\hline 40 and Above & 13.7 & & & \\
\hline \multicolumn{5}{|l|}{ Land Acquisition* } \\
\hline Inheritance & 81.4 & Leasehold & 20.6 & \\
\hline Gift & 33.3 & Purchase & 16.2 & \\
\hline Farm Size (Ha) & & & & 1.5 \\
\hline$\leq 1$ & 75.5 & $1.1-2.0$ & 6.4 & \\
\hline $2.1-3.0$ & 9.8 & $3.1-4.0$ & 5.4 & \\
\hline $4.1-5.0$ & 2.5 & & & \\
\hline Income (\#) & & & & 138,550 \\
\hline$\leq 50,000$ & 0.5 & $51,000-100,000$ & 9.8 & \\
\hline $101,000-150,000$ & 20.6 & $151,000-200,000$ & 23.0 & \\
\hline $201,000-250,000$ & 13.2 & $251,000-300,000$ & 10.8 & \\
\hline$>300,000$ & 21.6 & & & \\
\hline
\end{tabular}

${ }^{*}$ Multiple responses 
Creative commons User License: CC BY-NC-ND

Abstracted by: EBSCOhost, Electronic Journals Service (EJS),

Google Scholar, Directory of Open Access Journals (DOAJ),

Journal Seek, Scientific Commons,

Food and Agricultural Organization (FAO), andCABI
Journal of Agricultural Extension

Vol. 20 (1) June, 2016

ISSN(e): 24086851; ISSN(Print); 1119944X

http://journal.aesonnigeria.org

http://www.ajol.info/index.php/iae

Email: editorinchief@aesonnigeria.org

The majority (82.5\%) of the women rice farmers were married. This result agrees with the findings of Onumadu and Osahon (2014) where the majority of rice farmers were married. This implied that married people were more in rice farming and this could be as a result of more responsibilities they were saddled with as married people who had the role for providing household needs of their families.

More than $80 \%$ of the women rice farmers had below secondary education as indicated in Table 1. Education is an essential factor affecting desirable changes in attitude, skills and knowledge of individuals (Unamma, Onwudike, Uwaegbule, Edeoga and Nwosu2004). It could be inferred that rice farmers in the study area were literates who could read and write. This could serve as an impetus in adopting improved rice technologies. According to Amaza, Kwagbe and Amos (2004), and Akinnagbe and Ajayi (2010), education is an important factor influencing adoption of farm innovations.

About $98 \%$ of the rice producers were literate. This result contrast with the findings of Tsega, Alemu and Kiyoshi (2005) and Khattak and Hussain (2008) who found a high illiteracy level among rice farmers. Kebbeh, Haefele and Fagade (2003) also found that about 29 percent of rice farmers in Kaduna and Niger State of Nigeria did not have formal education. These results indicate that rice farmers might have good understanding of improved technologies about rice production, provided they are equally exposed to such technologies.

The average household size of the respondents was 10 persons (Table 1). This means that most of the women rice farmers in the study area had a fairly large household size which might serve as an insurance against short fall in supply of farm labour. Household size has a great role to play in family labour provision in agricultural sector. A large household will normally take much of the attention of the women farmer which reflects negatively on her productivity. This result disagrees with the findings of Adebayo (2001) that the size of household affects the output of women rice farmers.

The average farming experience of the farmers was 18 years. This indicates that the farmers were well experienced in rice farming. This implies that the women rice farmers were widely experienced, matured and could achieve a better understanding of adaptation strategies. The result revealed that the women rice farmers had reasonable years of experience.

Table 1 shows that the majority (81.4\%) of the women rice farmers inherit their farm lands. This result corroborates the findings of Kolawole et al. (2012). This result negates the report of Ajani (2008) that patriarchal structures and authorities give more resources to men in Nigeria, resulting in women having less access to productive resources, particularly land, which is perhaps the most economic constraint for most rural women. Similar to this finding, Fabiyi, Danladi, Akande and Mahmood (2007) found that the majority of the women farmers in Gombe State acquired land for farming from their husbands and relations (freehold), while others hired land for farming. Land tenure system should be reviewed in Nigeria. Women also should be made to enjoy land inheritance like men. Since the majority of women 
Creative commons User License: CC BY-NC-ND

Abstracted by: EBSCOhost, Electronic Journals Service (EJS),

Google Scholar, Directory of Open Access Journals (DOAJ),

Journal Seek, Scientific Commons,

Food and Agricultural Organization (FAO), andCABI
Journal of Agricultural Extension

Vol. 20 (1) June, 2016

ISSN(e): 24086851; ISSN(Print); 1119944X

http://journal.aesonnigeria.org

http://www.ajol.info/index.php/iae

Email: editorinchief@aesonnigeria.org

in rural areas are farmers, land availability for women will bring about increase in food production, self-reliance agricultural development and food security.

Furthermore, $75.5 \%$ of the women rice farmers cultivate 1 hectare and below as shown in Table 1. The result implies that most of the women rice farmers own small sizes of farmland. This may be attributable to the land tenure system prevalent in the study area which encourages small holdings. Saka and Lawal (2009) affirmed that the majority of small scale farmers in Nigeria are categorized as having 0.1-3.0 farm holdings. The size of a farm is a strong determinant of the expected output/yield (Abu, Pur and Ogunbameru, 2011). Land is the most important aspect in agriculture; without adequate land for food production, this may result to hunger, malnutrition, poverty and death. Inadequate farm land can limit the production capacity of agricultural produce.

Table 1 shows that the annual farm income from rice farming was 138,550 . This depicts a low level of income among women rice farmers in the study area. This may be due to their subsistent level of rice production. Akpabio (2005) argued that the poor income level of women farmers could be attributed to the subsistence level of farming prevalent in the rural areas.

\section{Socio-economic Factors Influencing Adoption of Recommended Rice Production Practices}

The adjusted $\mathrm{R}^{2}$ was 0.370 indicating that $37 \%$ of the contribution to recommended rice production practices' adoption was explained by the variables included in the model. Results of multiple regression analysis as shown in Table 2 revealed that only farm size was found to significantly influence adoption of recommended rice production practices $(2.860, \mathrm{P} \leq 0.01)$ by women rice farmers in the study area. This variable was a strong determinant of adoption of RRPPs among women rice farmers. A positive and significant relationship was found between women rice farmers' farm size and adoption of recommended rice production practices $(r=2.635, P \leq 0.05)$. Farmers with bigger farm size were better adopters, a result consistent with the findings of Ayoola, Dangbegnon, Daudu, Mando, Kudi, Amapu, Adeosun and Ezui (2011). The probability of adoption given large farm size is $97 \%$, making this factor the greatest driver of recommended rice production practices' adoption by women rice farmers. Agbamu (2006) asserted that, there exists a significant relationship between the adoption of new farm practices and size of land of farmers. Therefore, lack of adequate farm lands by the majority of the women rice farmers in the study area caused hindrance to adoption of improved technology due to the fact that they have only but little land to strive for their utilization and commercial purposes and might not be ready to take risks of trying any new production technology. Considering land as one of the main required factor in production, Abu et al. (2011) reported that small farm size could be a factor which prevents farmers from adopting innovation because of the inappropriateness of modern technologies to the economic realities of small scale farmers. 
Creative commons User License: CC BY-NC-ND

Abstracted by: EBSCOhost, Electronic Journals Service (EJS),

Google Scholar, Directory of Open Access Journals (DOAJ),

Journal Seek, Scientific Commons,

Food and Agricultural Organization (FAO), andCABI
Journal of Agricultural Extension

Vol. 20 (1) June, 2016

ISSN(e): 24086851; ISSN(Print); 1119944X

http://journal.aesonnigeria.org

http://www.ajol.info/index.php/jae

Email: editorinchief@aesonnigeria.org

Age $(r=0.015, P \leq 0.05)$, education $(r=0.147, P \leq 0.05)$, and household size $(r=0.038$, $\mathrm{P} \leq 0.05$ ) were not significant with the adoption of RRPPs. Farming experience had a negative value $(-0.044 ; \mathrm{P} \geq 0.05)$ but not significant to adoption of RRPPs. Household size had positive estimated coefficient toward the probability of adoption, but it was not significant at $5 \%$ level of probability. Ntege-Nanyeenya et al., 1997 found similar result. Contrary to apriori expectation, farmers' level of education did not influence adoption of RRPPs. This may not be unconnected with the fact that more than $80 \%$ of the women rice farmers had below secondary education as indicated in Table 1. According to Bonabana-Wabbi (2002) farmers' exposure to education increases their ability to obtain, process and utilize information relevant to the adoption of IPM technologies.

Table 2: Socio-economic characteristics influencing adoption of RRPPs by women rice farmers

\begin{tabular}{llll}
\hline Variables & Coefficient & Standard error & t-value \\
\hline Age & 0.0150 & 0.0763 & 0.200 \\
Marital status & 0.2268 & 0.7952 & 0.290 \\
Years of formal education & 0.1478 & 0.1324 & 1.120 \\
Household size & 0.0383 & 0.1031 & 0.370 \\
Farming experience & -0.0438 & 0.0657 & -0.670 \\
Farm size & 2.6353 & 0.9219 & $2.860^{* *}$ \\
\hline
\end{tabular}

F-value $=6.21^{* *} ; \mathrm{R}^{2}=0.396 ;$ Adjusted $\mathrm{R}^{2}=0.370$

** $\mathrm{P}<0.01$

\section{Women Rice Farmers' Constraints to Adoption of RRPPs}

Table 3 presents the result of constraints to adoption of recommended rice production practices by women rice farmers. Unavailability of loan facilities $(92.1 \%)$, poor marketing system and unstable price $(64 \%)$ as well as inadequate extension contacts $(61.6 \%)$ were the major constraint to adoption of RRPPs. Others major constraints include high cost of inputs (60\%), and adulteration of inputs (58.6\%). This result implies that women farmers were faced with myriads of constraints which limits their adoption of RRPPs. The implication of unavailability of credit facilities could be that the women rice farmers could not have the purchasing power for necessary farm inputs, which could reduce the level of adoption of rice production technologies among women rice farmers. Mustapha et al. (2012) found similar result. Agricultural production involves huge investments requiring availability of credit facilities to enhance and encourage adoption of technologies. Such credit facilities are mostly inaccessible by small farmers due to stringent conditions attached to its procurement. These conditions (e.g. high collateral, high interest rates, short moratorium) discourage small farmers (especially women who most of the times do not own major assets) from accessing the credit facilities. Poor pricing of agricultural produce especially at the time of glut makes rice farming unprofitable thereby discouraging expansion of farm and consequently limiting adoption of proven technologies. Extension contact is supposed to enhance adoption. This is expected to be achieved 
by effective dissemination of technologies using various methods including regular training on the use of available technologies generated from research stations. The dwindling number of extension personnel in the State ADPs has been reported by NAERLS and FDAE (2014) as alarming.

\section{Table 3: Women rice farmers' constraints to adoption of RRPPs}

\begin{tabular}{lll}
\hline Constraints to Adoption of RRPPs & Percent & Rank \\
\hline Unavailability of credit facilities & 92.1 & $1^{\text {st }}$ \\
Poor marketing system and unstable market prices & 64.0 & $2^{\text {nd }}$ \\
Poor extension contact & 61.6 & $3^{\text {rd }}$ \\
High cost of inputs & 60.0 & $4^{\text {th }}$ \\
Adulteration of herbicides & 58.6 & $5^{\text {th }}$ \\
Natural hazard, floods and drought & 54.7 & $6^{\text {th }}$ \\
High cost of tractor hiring and unavailable machineries & 47.8 & $7^{\text {th }}$ \\
Land tenure problem & 38.9 & $8^{\text {th }}$ \\
Transportation constraints & 33.5 & $9^{\text {th }}$ \\
Prevalence of pests and diseases & 32.0 & $10^{\text {th }}$ \\
High cost of labour & 22.2 & $11^{\text {th }}$ \\
Planting space of 25 x 25 cm is difficult & 20.7 & $12^{\text {th }}$ \\
Low level of willingness to cultivate rice by young women & 14.3 & $13^{\text {th }}$ \\
Poor storage system & 13.8 & $14^{\text {th }}$ \\
Untimely availability of fertilizer & 10.3 & $15^{\text {th }}$ \\
Language barrier & 0.7 & $16^{\text {th }}$ \\
\hline
\end{tabular}

*Multiple responses

\section{Conclusion and Recommendations}

Adoption of recommended rice production practices was significantly influenced by farm size. Constraints hindering adoption of RRPPs were unavailability of credit facilities, poor marketing system and unstable price, and inadequate extension contacts.

Relevant agencies should make credit facilities accessible to women farmers through removal of stringent conditions attached to credit assessment. Also, Government should introduce an efficient marketing system involving a buy-back arrangement for farmers' produce with appropriate pricing system similar to the commodity marketing board. More so, extension should facilitate the formation and management of viable women cooperatives to enhance pulling of resources to combat the constraints in rice production and enhance adoption of recommended rice production practices. This facilitation can be achieved by creating awareness on the importance of being in groups, and providing necessary training for effective and efficient management of such group. 
Creative commons User License: CC BY-NC-ND

Abstracted by: EBSCOhost, Electronic Journals Service (EJS),

Google Scholar, Directory of Open Access Journals (DOAJ),

Journal Seek, Scientific Commons,

Food and Agricultural Organization (FAO), andCABI
Journal of Agricultural Extension

Vol. 20 (1) June, 2016

ISSN(e): 24086851; ISSN(Print); 1119944X

http://journal.aesonnigeria.org

http://www.ajol.info/index.php/jae

Email: editorinchief@aesonnigeria.org

\section{References}

Abu, I. A., Pur, J. T. and Ogunbameru, B. O. (2011). Analysis of socio economic factors influencing the adoption of rice technologies by farmers in Borno State, Nigeria, Adamawa State University Journal of Agricultural Sciences, 1(1): 40-45.

Adebayo, E. F. (2001). Determinants of rice production by women farmers in Yola area of Adamawa State, Nigeria. Journal of Arid Agriculture, 17:69-74.

Agbamu, J. U. (2006). Adoption and diffusion process for Agricultural Innovation Communication in Nigeria. Department of Agricultural Economics and Extension, Delta State, Asaba, Nigeria, Matthouse Press Ltd. Victoria Island Lagos, pp. 47-81.

Ajani, O. I. (2008). Gender dimensions in agriculture, poverty, nutrition and food security in Nigeria. Nigeria Strategy Support Program (NSSP). IFPRI. Pp 5-7.

Akande, T. (2000). An overview of the Nigerian rice economy. Nigerian Institute of Social and Economic Research (NISER) Annual: report. Ibadan, Nigeria. pp 47.

Akinnagbe, O. M. and Ajayi, A. R. (2010). Assessment of farmers' benefits derived from Olam organization sustainable cocoa production extension activities in Ondo State, Nigeria. Journal of Agricultural Extension. 14 (1): 13 - 24.

Akpabio, I. (2005). Human agriculture, social themes in agricultural development. Abam Publishing Company, Uyo, Akwa Ibom State, Nigeria.

Amaza, P. S.; Kwagbe, P. V. and Amos, A.A. (2004). Analysis of women's participation in agricultural cooperatives: Case study of Borno State, Nigeria. Anals of Borno 15/16: 187-196.

Ayoola, G. B. (2007). National Council on Agriculture and Rural Development. Analytical Profile of the Policy Advisory Body on Nigerian Agricultural and Rural Development. Farm and Infrastructure Foundation Annual report. Ibadan, Nigeria.

Ayoola, J. B.; Dangbegnon, C., Daudu, C.K., Mando, A., Kudi, T.M., Amapu, I.Y., Adeosun, J.O. and Ezui, K. S. (2011). Socio-economic factors influencing rice production among male and female farmers in Northern Guinea Savanna Nigeria: lessons for promoting gender equity in action research. Agriculture and Biology Journal of North America. 2(6), pp1010 - 1014.

Badawi, T. A. (2004). Rice Based Production System for Food Security and Poverty Alleviation in the Near-East and North Africa. New Challenges and Technological Opportunities, FAO Rice Conference proceeding Held at Rome Italy. in: http://www.faw.org/rice2004/en/pdf.badawi.pdf

Bonabana-Wabbi, J. (2002). Assessing factors affecting adoption of agricultural technologies: The case of Integrated Pest Management (IPM) in Kumi District, Eastern Uganda. MSc (Agricultural and Applied Economics) Thesis submitted to the faculty of the Virginia Polytechnic Institute and State University. 146 pp.

Central Bank of Nigeria (CBN) (2004): Annual report and statement of Accounts, CBN publication.

Fabiyi, E.F., Danladi, B. B., Akande, K.E. and Mahmood, Y. Y. (2007). Role of women in agricultural development and their constraints: A Case Study of Biliri Local Government Area, Gombe State, Nigeria. Pakistan Journal of Nutrition 6 (6): 676680. 
Creative commons User License: CC BY-NC-ND

Abstracted by: EBSCOhost, Electronic Journals Service (EJS),

Google Scholar, Directory of Open Access Journals (DOAJ),

Journal Seek, Scientific Commons,

Food and Agricultural Organization (FAO), andCABI
Journal of Agricultural Extension

Vol. 20 (1) June, 2016

ISSN(e): 24086851; ISSN(Print); 1119944X

http://journal.aesonnigeria.org

http://www.ajol.info/index.php/iae

Email: editorinchief@aesonnigeria.org

Famoriyo, S. (1979). Land Tenure and Agricultural Development in Nigeria, NISER, Ibadan.

Federal Ministry of Agriculture and Rural Development (FMARD) (2011). Agricultural Transformation Agenda Main Report. Sept. Pp 93.

Federal Ministry of Agriculture and Rural Development (FMARD) (2012). Rice Transformation Action Plan. Sept. Pp 45.

Folasade, K. F. (1991). The roles of women in food production in Oyo LGA of Ondo State. B. Sc Thesis, Department of Agricultural Extension and Rural Sociology, Obafemi Awolowo University lle-Ife, Nigeria.

Food and Agriculture Organization (FAO) (2006). Agriculture towards 2015/30: Technical Interim Reports on Rice Production and Demands in Sub-Saharan Africa. 11 (1).1-3, FAO, Rome, Italy.

Food and Agriculture Organization (FAO) (2008). Rice information vol. 12, Food and Agricultural organization, Rome, Italy.

Fresco, L.O. (1998). Higher Agricultural Education: An opportunity in rural development for women. Sustainable development department, Food and Agricultural Organisation (FAO), for the United Nations. Pp 4.

Imolehin, E.D. and Wada, A.C. (2010). Meeting the rice production and consumption demands of Nigeria with improved technologies. An Article of the National Cereals Research Institute, Badeggi, Niger State Nigeria. www.fad.org/docrep.htm. Retrieved on 13th February, 2012.

Kebbeh, M., Haefele, S. and Fagade, S. O. (2003). Challenges and opportunities for improving irrigated rice productivity in Nigeria. Abidjan: WARDA.

Khattak, N. R.K. and Hussain, A. H. (2008). An analysis of socioeconomic profile of rural rice farmers in District Swat. Sarhad J. Agric. Vol.24, No.2. 377 - 382. MPRA Paper No. 42035. Available Online at http://mpra.ub.uni-muenchen.de/42035/Assessed 9th june 2014.

Kolawole, A., Oladele, O. I., Alarima, C.I. and Wakatsuki, T. (2012). Farmers' perception of sawah rice production technology in Nigeria. J Hum Ecol, 37(1): 13-17.

Mustapha, S. B., Undiandeye, U. C., Sanusi, A. M., Bakari, S. (2012). Analysis of adoption of improved rice production technologies in Jeer local government area of Borno state, Nigeria. International Journal of Development and Sustainability. Volume 1 Number 3: Pp 1112-1120.

Nasarawa State Agricultural Development Project (NADP) (2010). Annual Reports.

National Agricultural Extension and Research Liaison Services (NAERLS) and Federal Department of Agricultural Extension (FDAE), (2014). Agricultural performance survey of 2014 wet season in Nigeria, Executive summary. October. Pp 23.

National Population Commission (NPC) (2006). National Population Census Provisional Report for Nigeria: Draft Report - Nasarawa State, Nigeria.

Ntege-Nanyeenya, W., Mugisa-Mutetikka, M., Mwangi, W., and Verkuijl, H. (1997). An assessment of factors affecting adoption of maize production technologies in Iganga 
Creative commons User License: CC BY-NC-ND

Abstracted by: EBSCOhost, Electronic Journals Service (EJS),

Google Scholar, Directory of Open Access Journals (DOAJ),

Journal Seek, Scientific Commons,

Food and Agricultural Organization (FAO), andCABI
Journal of Agricultural Extension

Vol. 20 (1) June, 2016

ISSN(e): 24086851; ISSN(Print); 1119944X

http://journal.aesonnigeria.org

http://www.ajol.info/index.php/jae

Email: editorinchief@aesonnigeria.org

District, Uganda. Addis Ababa, Ethiopia: National Agricultural Research Organization (NARO) and International Maize and Wheat Improvement Center (CIMMYT).

Onumadu, F. N. and Osahon, E. E. (2014). Socio-economic determinants of adoption of improved rice technology by farmers in Ayamelum Local Government Area of Anambra State, Nigeria. International Journal of Scientific \& Technology Research Volume 3, Issue 1, January pp $308-314$.

Saito, K.A. and Surling, D. (1993). Developing agricultural extension for women farmers. World Bank Discussion paper No 5, pp 20-25.

Saka, J. O., Okoruwa, B.O., Ajibola, S. (2005). Adoption of improve rice varieties among small-holder farmers in South-Western Nigeria. World Journal of Agricultural Science. 1(1): 32-49.

Saka, J. O. and Lawal, B. O. (2009). Determinants of adoption and productivity of improved rice varieties in Southwestern Nigeria. African Journal of Biotechnology. 8(19): 4923 - 4932.

Tsega, M.M., Alemu, D. and Kiyoshi, S. (2005). Socioeconomic characteristics of smallholder rice production in Ethiopia. Research Report 100 Ethiopian Institute of Agricultural Research, pp 53.

Unamma, R. P. A, Onwudike, O. C. Uwaegbule, A. C. Edeoga, H. O. and Nwosu, A. C. (2004). Farming System Research and Development in Nigeria. Principles and Practice in Humid and Derived Savanna Southeast Zone. Published by Michael Okpara University of Agriculture Umudike, Nigeria Pp 152 and 283.

United Nations (UN) (1986). World Survey on the Role of women in Development. Published by Department of International and Social Affairs, pp: 12.

West African Rice Development Association (WARDA) (2006). Annual Reports. International Rice Commission. Cote D'voire.

West African Rice Development Association (WARDA) (2003). Rice Trends in SubSaharan African: A Synthesis of Statistics on Rice Production, Trade and Consumption, UK, Sayce Publishing, pp. 1-22.

West African Rice Development Association and Nigeria Institute of social and Economic Research (WARDA and NISER) (2001). Report of the stakeholder workshop. WARDA and NISER, Ibadan, Nigeria 8-9 November.

Yahaya, M. K. (2002). Gender and communication variables in agricultural information dissemination in two Agro-ecological Zones of Nigeria. Research monograph, University of Ibadan, pp: 68. 